exertions are necessary to catch it, although its movements are in themselves extremely clumsy.

\title{
F. Food.
}

The food of the Seals on the Fro Islands seems to be principally fish; Halibut (Hippoglossus vulgaris) appears to be a delicacy to them. As a proof that they fetch their food from a considerable depth, it is related that a few years ago a young one was found caught by one of the hooks of a fishing-line that was placed at a depth of between 70 and 80 fathoms on the outer side of one of the islands. Grey Seals have several times been seen to come up to the surface with Lings (Molva vulgaris), and other deep-water fishes in their mouths, such fishes being seldom or never found at a less depth than between 60 and 70 fathoms.

There has never been any success with attempts made to rear young Grey Seals in confinement, although it has been tried several times on the Fro Islands.

3. A Note on Rhipidura preissi, Cab. By R. Bowdler Sharpe, F.L.S., F.Z.S., \&c., Senior Assistant, Department of Zoology, British Museum.

[Received February 23, 1881.]

When I wrote the fourth volume of the 'Catalogue of Birds' I was unable to say any thing about the Fantail Flycatcher of Western Australia (Rhipidura preissi), as no specimen existed at that time in any English collection, nor had it been figured by Gould in his Supplement to the 'Birds of Australia.' In fact, since it was described in 1850 by Dr. Cabanis, I believe that nothing whatever has been written concerning the species. I was pleased, therefore, on visiting Birmingham last November, to find an interesting collection of birds in that town in the possession of $\mathrm{Mr}$. Walter Chamberlain, who obtained all his specimens himself during his travels in the Australian and Indian regions. Amongst other rarities, he had an example of Rhipidura preissi, shot in King George's Sound in Western Australia ; and he very kindly responded to my request to lend me the specimen.

I find that, as stated by Dr. Cabanis, the species is very closely allied to $R$. albiscapa, but is more slaty brown, and differs in the grey spot on the throat, which is much lighter than in $R$. pelzelni, with which species I at one time supposed it might be identical. It seems to me to be a good species, if indeed any of these whiteshafted Fantails are really worthy of specitic rank; I think that they are rather races of one species, varying with locality.

The following is a description of Mr. Chamberlain's specimen :- 


\section{RHIPIDURA PREISSI.}

Rhipidura preissi, Cab. Mus. Hein. Th. i. p. 57 (1850); Gould, Handb. B. Austr. i. p. 240 (1865) ; Gray, Hand-l. B. i. p. 331, no. 4972 (1869) ; Ramsay, Pr. Linn. Soc. N.S.W. ii. p. 182 (1878); Sharpe, Cat. B. Brit. Mus. iv. p. 310, note (1879).

Adult. General colour above slaty brown, the head scarcely darker than the back; wing-coverts like the back, the greater series rather browner, and tipped with white like the median series, so as to form a double wing-bar ; primary-coverts and quills brown, the inner secondaries externally bordered with white; tail-feathers brown, the two centre ones black-shafted, the others with white shafts and tipped with white, which extends down the inner web from the tip, increasing in extent towards the outermost, which has the outer web entirely white; lores, sides of face, and ear-coverts blackish, with a faint indication of a whitish streak over the fore part of the eye ; throat whitish; remainder of under surface light ochraceous buff, becoming dull white on the under tail-coverts ; the sides of the breast and the lower throat and fore neck ashy grey, the latter streaked with the same colour as the breast; under wing-coverts white, dusky internally; quills dusky brown below, lighter along the edge of the inner web. Total length 5.4 inches, culmen 0.3 , wing $2 \cdot 7$, tail $3 \cdot 25$, tarsus $0 \cdot 65$.

On looking over my "Key to the Species" of these white-shafted Fantails, I am not quite satisfied with their arrangement, and would modify the characters given on pp. 303 and 304 of the Catalogue, as follows :-

a. Three or more outer tail-feathers with entirely white or creamy-white shafts.

$a^{\prime}$. Centre tail-feathers with white shafts like the others

$b^{\prime}$. Two centre tail-feathers with brown shafts, the rest with

$\{$ flabellifera. white ones.

$a^{\prime \prime}$. Breast not scaly, i.e. not mottled with dark centres to the feathers, but uniform ochraceous buff; throat white, with a patch of black or dull grey on the lower portion.

$a^{\prime}$. Outer web of external tail-feathers pure white for its whole extent.

$a^{4}$. Throat-patch black

$\left\{\begin{array}{l}\text { albiscapa. } \\ \text { saturata. }\end{array}\right.$

$b^{4}$. Throat-patch grey, the fore neck also grey, streaked with ochraceous buff like the rest of the under surface

$b^{\prime \prime}$. Outer web of external tail-feathers dull white, brownish towards the tip

$c^{\prime \prime \prime}$. Outer web of external tail-feathers smoky brown, as also the tips to all the tail-feathers

$\left\{\begin{array}{l}\text { bulgeri. } \\ \text { blabellifer }\end{array}\right.$

preissi.

pelzelni.

brenchleyi. 


\section{$2 \mathrm{BHL}$ Biodiversity Heritage Library}

Sharpe, Richard Bowdler. 1881. "A Note on Rhipidura preissi, Cab."

Proceedings of the Zoological Society of London 1881, 387-388.

https://doi.org/10.1111/j.1096-3642.1881.tb01294.x.

View This Item Online: https://www.biodiversitylibrary.org/item/96698

DOI: https://doi.org/10.1111/j.1096-3642.1881.tb01294.x

Permalink: https://www.biodiversitylibrary.org/partpdf/73292

\section{Holding Institution}

Natural History Museum Library, London

\section{Sponsored by}

Natural History Museum Library, London

\section{Copyright \& Reuse}

Copyright Status: Public domain. The BHL considers that this work is no longer under copyright protection.

This document was created from content at the Biodiversity Heritage Library, the world's largest open access digital library for biodiversity literature and archives. Visit BHL at https://www.biodiversitylibrary.org. 